биологии: мат-лы XII всерос. популяционного семинара памяти Николая Васильевича Глотова (19392016), Йошкар-Ола, 11-14 апреля 2017 г. ЙошкарОла: ООО ИПФ «Стринг». С. 220-221.

21. Суетина Ю.Г., Высокова Е.С., Х Хамидуллина И.И. Имматурные особи в онтогенетической структуре популяций эпифитных лишайников Evernia prunastri (L.) Ach. и Hypogymnia physodes (L.) Nyl. // Проблемы популяционной биологии: мат-лы XII всерос. популяционного семинара памяти Николая
Васильевича Глотова (1939-2016). Йошкар-Ола: ООО ИПФ «Стринг», 2017. С. 216-217.

22. Михайлова И.Н., Воробейчик Е.Л. Размерная и возрастная структура популяций эпифитного лишайника Hypogymnia physodes (L.) Nyl. в условиях атмосферного загрязнения // Экология. 1999. № 2. C. $130-137$.

Работа выполнена при частичной финансовой поддержке гранта РФФИ (проект № 16-04-01198 a).

\title{
DYNAMICS OF EVERNIA PRUNASTRI (L.) ACH. AND HYPOGYMNIA PHYSODES (L.) NYL. POPULATION STRUCTURE ON TILIA CORDATA MILL. IN THE FLOODED LIME-TREE FOREST OF THE BOLSHAYA KOKSHAGA RIVER
}

\section{(C) 2019}

Suetina Yulia Gennadyevna, candidate of biological sciences, associate professor of Biology Department Mari State University (Yoshkar-Ola, Russian Federation)

Ivanov Sergey Mikhailovich, candidate of biological sciences, software developer Simple World LLC (Yoshkar-Ola, Russian Federation)

Abstract. The paper deals with perennial dynamics of the population structure of the epiphytic lichens Evernia prunastri (L.) Ach. (2008-2016) and Hypogymnia physodes (L.) Nyl. (2010-2016) with the different life forms and the ecological strategies. The research was carried out in the Mari El Republic in the flooded lime-tree forest. The authors studied the density (number of thalli on a tree) on the trunk from 0 to 1,5 meters, the size and the ontogenetic structure of population of both species of different ontogenetic states: virginile $\left(\mathrm{v}_{1}, \mathrm{v}_{2}\right)$, potentially generative $\left(\mathrm{g}_{1} \mathrm{v}\right.$, $\mathrm{g}_{2} \mathrm{v}, \mathrm{g}_{3} \mathrm{v}$ ), subsenile (ss) on 17 trees of Tilia cordata. The density of E. prunastri and $H$. physodes population increases. These changes are more specific for E. prunastri. Thalli of E. prunastri have a bigger size than thalli of H. physodes. These differences are observed on $\mathrm{g}_{1} \mathrm{v}, \mathrm{g}_{2} \mathrm{~V}, \mathrm{~g}_{3} \mathrm{~V}$, ss thalli. The decrease of thalli size is observed for both species but the difference is more for E. prunastri. The comparison of ontogenetic spectra of populations was made according to their heterogeneity within trees. The values of the effects (the effect is the parameter of the ontogenetic spectrum of the population) decreased in 2016, which indicated a shift of the ontogenetic spectra to the left, i.e. an increase in the proportion of young thalli that can be traced in the total ontogenetic spectra of populations. At the same time, the differences between the ontogenetic spectra of the E. prunastri population are statistically significant.

Keywords: epiphytic lichens; fruticose lichen; Evernia prunastri; foliose lichen; Hypogymnia physodes; Tilia cordata; population dynamics; population density; ontogenetic structure of populations; dimensional structure of populations; fitness; flooded lime-tree forest; Bolshaya Kokshaga river; Mari El Republic.

УДК 911:502

DOI 10.24411/2309-4370-2019-11120

Статья поступила в редакцию 20.01.2019

\section{РЕИНТРОДУКЦИЯ ЛОШАДИ ПРЖЕВАЛЬСКОГО В ГОСУДАРСТВЕННОМ ПРИРОДНОМ ЗАПОВЕДНИКЕ «ОРЕНБУРГСКИЙ»: ПЕРВЫЕ ИТОГИ} (C) 2019

Тюрин Александр Николаевич, кандидат географических наук, доцент кафедры географии и методики преподавания географических дисциплин Оренбургский государственный педагогический университет (г. Оренбург, Российская Федерация)

Аннотация. В данной статье представлена хронология основных событий, происходящих в рамках программы по переселению и заселению вновь лошадей Пржевальского на территорию, где обитали их близкие родственники - тарпаны, для создания новой и устойчивой популяции этих животных. Популяция лошади Пржевальского в естественных условиях Оренбургского государственного природного заповедника позволит иметь резерв здоровых, хорошо развитых животных как гарантию сохранения вида в чистоте на протяжении длительного периода времени. К концу XIX века в естественной среде обитания не осталось ни одной дикой лошади Пржевальского. В статье рассматривается поэтапная реинтродукция лошади Пржевальского и представлены первые результаты, взятые из открытых источников, по восстановления популяции дикой лошади в Оренбургской области. Первые итоги позволяют с уверенностью смотреть в будущее. В заповеднике уже родилось 5 здоровых жеребят; учёные ООПТ надеются, что в 2019 г. поголовье дикой лошади продолжит расти. Программа по реинтродукции лошади Пржевальского пользуется личной поддержкой губернатора Оренбургской области и вошла в число ключевых проектов по охране диких животных под патронажем Президента Российской Федерации.

Ключевые слова: лошадь Пржевальского; дикая лошадь; гаремная группа животных; вымирающий вид; Оренбургская область; Государственный природный заповедник «Оренбургский»; кластерный заповедник; «Предуральская степь»; «Оренбургская Тарпания»; исторический ареал; заповедный режим; популяция; акклиматизация. 


\section{Введение}

Известный путешественник Н.М. Пржевальский в конце XVIII века описал в своих дневниках и сообщил всему научному сообществу мира о дикой монгольской лошади, которую в дальнейшем назвали его именем. Песочного цвета, даже рыжеватая, с плотным телосложением, абсолютно дикая и не поддающаяся дрессировке, она имела явные преимущества и успешно конкурировала с домашними лошадьми за водопои и пастбища [1] (рис. 1).

Скотоводы Центральной Азии, недовольные таким положением дел, в качестве решения данной проблемы обычно прибегали к помощи ружей, поэтому к концу XIX века в естественной среде обитания лошади Пржевальского больше не наблюдались [2, c. 138].

Для спасения лошади Пржевальского как вида удалось размножить этих животных в неволе на базе крупных зоопарков мира и подготовить их к жизни в дикой природе. C конца XX века начались первые попытки реинтродукции лошади Пржевальского в Монголии, Франции, Венгрии, на Украине, а в настоящее время и в России (Оренбургская область).

Реинтродукция лошади Пржевальского осуществляется на самом крупном участке кластерного Государственного природного заповедника «Оренбургский» - «Предуральская степь». 5 участков заповедника находятся в 5 административных районах Оренбургской области: «Айтуарская степь» (Кувандыкский район), «Ащисайская степь» (Светлинский район), «Буртинская степь» (Беляевский район), «Таловская степь» (Первомайский район) и «Предуральская степь» (на границе Акбулакского и Беляевского районов Оренбургской области).

«Предуральская степь»- один из немногих в России достаточно крупный сохранившийся в естественных условиях участок целинной типичной ковыльной степи, требующий сохранения для будущих поколений. Данный участок представляет собой уни- кальный природный объект, особенностью которого являются сохранившиеся компактные массивы зональных ареалов степной растительности [3].

Это территория бывшего военного полигона, в период освоения целины она оказалась изъята из сельскохозяйственного производства и была включена в земли Министерства вооружённых сил СССР. Деятельность человека на данном объекте имела ограниченный характер, в результате чего на данной территории оказались нетронутыми большие пространства настоящих степей $[4 ; 5]$.

Географически «Предуральская степь» располагается на водораздельной части левых притоков р. Урал, а именно в междуречье р. Урта-Буртя и р. Буртя; в периметре имеет размеры $10 \times 16$ км и площадь порядка 16 тыс. га. Ландшафтная структура уникальна и представлена главным образом степными плакорами. Другую часть территории составляют увалисто-холмистые провинции. Почвы представлены чернозёмами южными песчаными и супесчаными по гранулометрическому составу [6-9; 10, с. 79; 11].

Растительное сообщество в степи сформировано разнотравно-тонконогово-красноковыльными и разнотравно-типчаково-ковылковыми ассоциациями. Исторически сложилось присутствие в данных природных сообществах копытных животных. Ещё два столетия назад на степных просторах Оренбургского края паслись два вида диких лошадей: лошадь Пржевальского и её ближайший родственник - тарпан [3; $12 ; 13$, c. 11].

\section{Объект исследования}

Лошадь Пржевальского - это дикая лошадь, обитавшая в степях Евразии, поголовье которой в начале $\mathrm{XX}$ века стало резко сокращаться. Активная охота на этих животных, а также низкие зимние температуры 1940-х годов в ареале обитания данного вида способствовали сокращению численности лошади Пржевальского: сначала они стали крайне редки, а затем и вовсе исчезли.

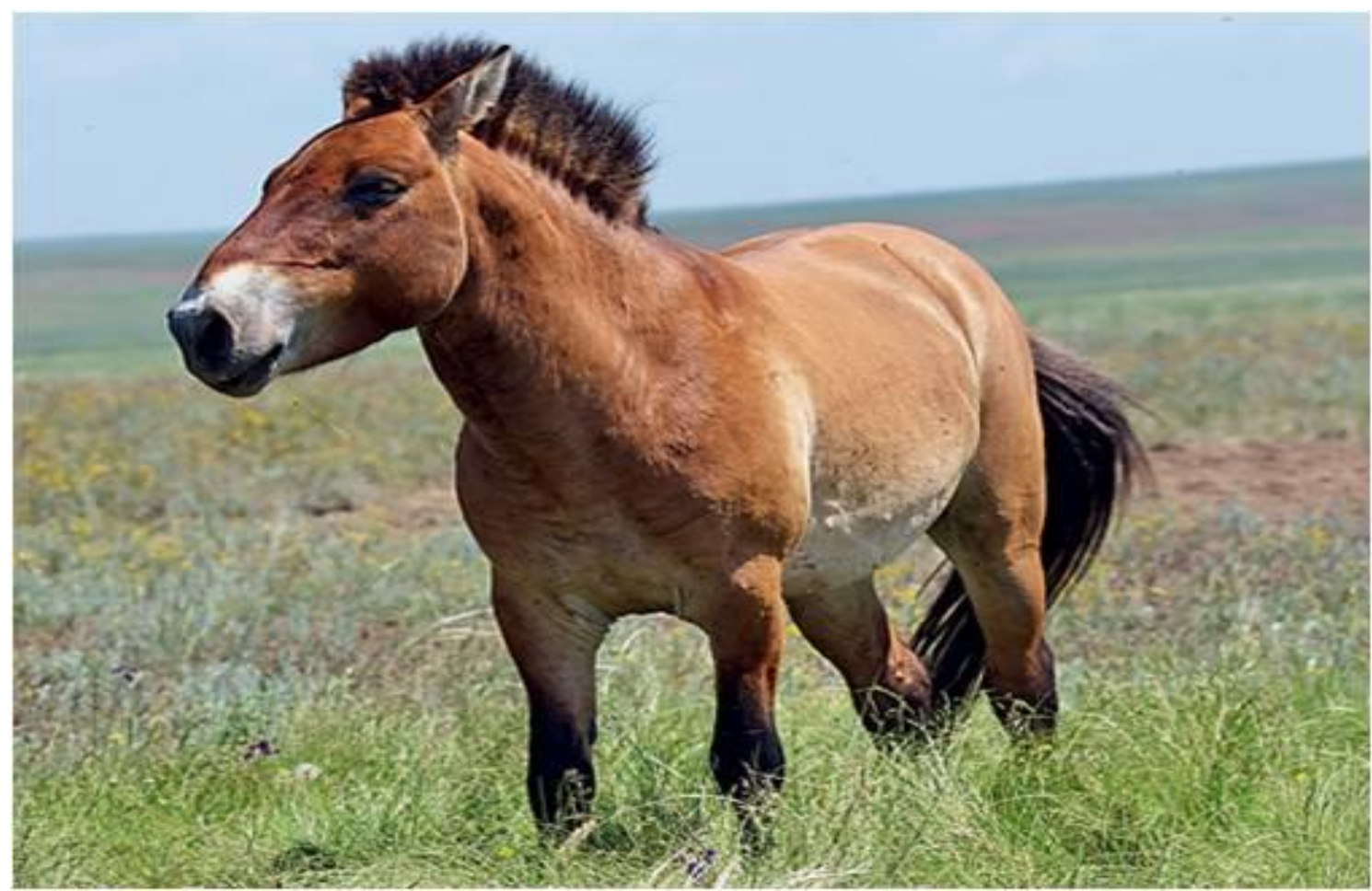

Рисунок 1 - Лошадь Пржевальского (фото Т.Л. Жарких) 


\section{Материалы и методика исследований}

Реинтродукция лошади Пржевальского в полувольную среду обитания в границах участка «Предуральская степь» Государственного природного заповедника «Оренбургский» изучалась методом наблюдения, сравнения, анализа литературных источников и публикаций по данной тематике, а также сравнительно-географическим и экспериментально-аналитическими методами.

Теоретически реинтродукция в неволе не может проводиться постоянно. После конечного числа поколений (в зависимости от размеров популяции) группа животных начнет проявлять признаки одомашнивания, случайных изменений и инбредной депрессии. Кроме того, возможность реинтродукции невелика в таких государствах, где в настоящее время наблюдается демографический подъём. Однако во время проведения программ по восстановлению в неволе вымирающих видов животных могут появиться новые возможности для реализации проектов. Поэтому проводить реинтродукцию, насколько это может быть экономически целесообразно и технически возможно, - необходимо [14, с. 297].

\section{Результаты исследований и их обсуждение}

Нами составлена хронология основных событий, произошедших в ходе реализации проектов по реинтродукции лошади Пржевальского:

2013 год. В охранной зоне заповедника «Оренбургский» начал свою работу Центр разведения степных животных. Центр был открыт в рамках проекта по реинтродукции лошади Пржевальского «Оренбургская Тарпания» Оренбургским отделением Русского географического общества и Институтом степи Уральского отделения РАН при поддержке Попечительского совета регионального отделения РГО [15, с. $358 ; 16$, с. $13 ; 17$, с. 37$]$.

Май и октябрь 2014 года. В Оренбургскую область из Московского зоопарка, а также из Хотынецкого вольерного комплекса Орловской области завезены три первые лошади Пржевальского [18].

2015 год. Объединенная дирекция государственных природных заповедников «Оренбургский» и «Шайтан-Тау» (ФГБУ «Заповедники Оренбуржья») приступила к реализации основной части Программы восстановления лошади Пржевальского в Оренбургской области [19].

18 октября 2015 года. Из Франции в Оренбургский заповедник прибыли 6 особей лошади Пржевальского (2 жеребца и 4 кобылы). Причём изначально планировался перелёт 10 лошадей, но 4 диких лошади воспротивились перевозке [20].
3 октября 2016 года. Из акклиматизационного загона Центра реинтродукции на территорию заповедника «Предуральская степь» были выпущены 6 диких лошадей Пржевальского. В мероприятии лично участвовал Президент Российской Федерации В.В. Путин.

20 ноября 2016 года. Из венгерского национального парка «Хортобадь» в Государственный природный заповедник «Оренбургский» завезена очередная партия лошадей Пржевальского, 14 особей (среди которых 5 жеребцов и 9 кобыл) (рис. 2).

28 сентября 2017 года. Лошадиный гарем из восьми кобыл и жеребца, доставленных из Венгрии, покинул акклиматизационный загон заповедника. Семья лошадей присоединилась к гарему из Франции, который годом ранее уже был отправлен на полувольное содержание.

10 октября 2017 года. Новая партия из 16 особей лошади Пржевальского (12 молодых кобыл и 4 жеребца) прибыли в Оренбургский заповедник [21].

11 июня 2018 года. Родился первый жеребенок лошади Пржевальского в рамках проекта по реинтродукции этого вида в Оренбургской области (рис. 3). Имя жеребёнку дали Арнак, что означает «дикий». Жеребенок Арнак стал первым за 3 года реализации программы в табуне полувольноживущей популяции (вероятнее всего, это стало следствием нарушения репродуктивных функций животных, связанных с подготовкой диких лошадей к транспортировке в Россию). Было принято решение всем жеребятам, рожденным в 2018 году, давать имена на букву «а». Это было сделано, чтобы впоследствии упростить регистрацию и контроль за лошадьми Пржевальского.

14 июня 2018 года. Другая кобыла родила жеребенка, которого назвали Атас, что в переводе со скифского означает «бесстрашный». В этот же день родился третий жеребёнок Аргот, который назван в честь одного из скифских царей V в. до н.э. Все жеребята оказались самцами, поэтому стараются держаться вместе, несмотря на некоторую разницу в возрасте.

18 сентября 2018 года. На свет появился четвертый жеребенок. Жеребенку было дано сарматское имя - Азарм, что означает «направляющая десница». Дикие лошади позволяли персоналу заповедника визуально осматривать мать и новорождённого. По всем признакам, оба являлись абсолютно здоровыми. Ориентировочный вес жеребёнка составил 25-30 кг.

14 октября 2018 года. Родилась самка, которой дали имя Агама (в переводе с сарматского: «сильная, могучая»).

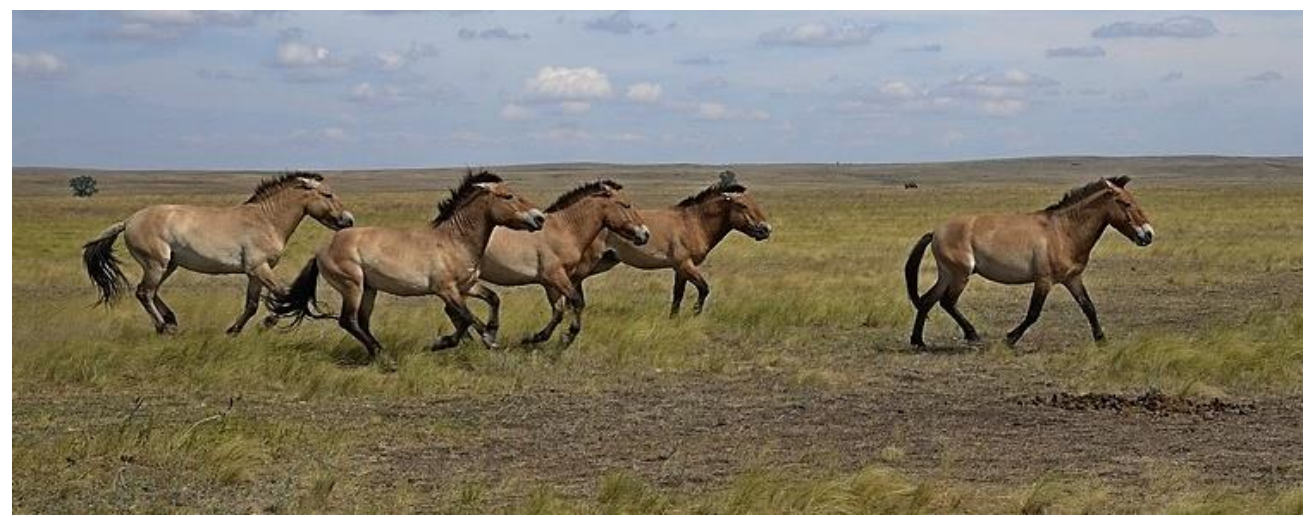

Рисунок 2 - Лошади Пржевальского в оренбургских степях (фото Т.Л. Жарких) 


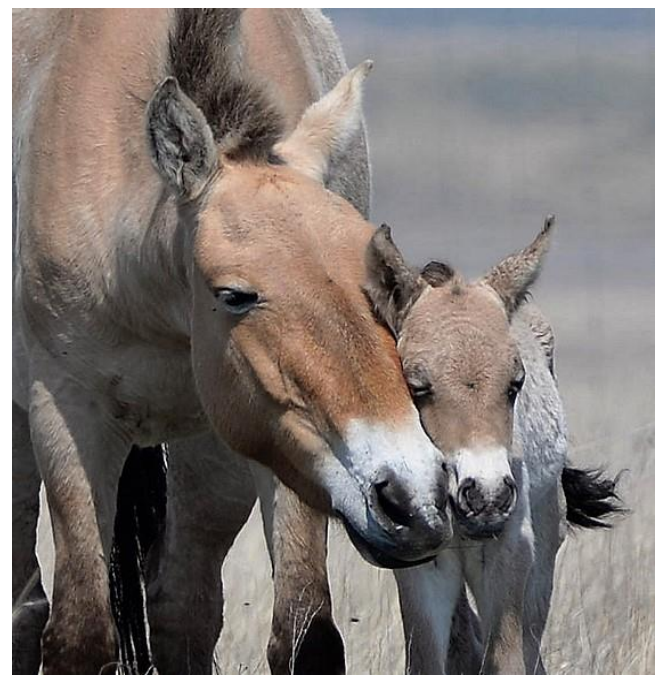

Рисунок 3 - Первый жеребенок, рождённый в заповеднике «Оренбургский» (фото Т.Л. Жарких)

\section{Выводы}

В начале 2019 года мы подводим первые итоги реализации Программы по реинтродукции лошади Пржевальского в Оренбургской области.

В настоящее время в загонах остаются две группы кобыл и жеребцов-холостяков, а на главной территории заповедника живут три гаремные группы. Рождение первых вольных жеребят является свидетельством успешной акклиматизации животных в России, их хорошего здоровья и говорит об успехе проекта в целом. В настоящий момент на территории заповедника обитает 39 лошадей Пржевальского.

Первый этап Программы рассчитан на 15 лет и будет продолжаться до 2030 г. На данном этапе в Оренбургской области должна быть реинтродуцирована полувольная самоподдерживающаяся популяция лошади Пржевальского общей численностью от 120 до 150 особей.

\section{Список литературы:}

1. Пржевальский Н.М. От Кульджи за Тянь-Шань и на Лобнор. М.: Государственное издательство географической литературы, 1947. 155 с.

2. Мироненко С.С. Лошадь Пржевальского возвращается в степь // Наука и жизнь. 2016. № 7. С. $138-144$.

3. Оренбургский заповедник: значение для сохранения степных экосистем России и перспективы развития: Труды Государственного природного заповедника «Оренбургский». Вып. І. Оренбург: ИПК «Газпромпечать» ООО «Оренбурггазпромсервис», 2014. $172 \mathrm{c}$.

4. Чибилёв А.А. Степи Оренбургские. К 25-летию создания заповедника «Оренбургский». ОренбургЕкатеринбург: Институт степи УрО РАН; Оренбургское отделение Русского географического общества, 2014. 152 c.

5. Чибилёв А.А. Заповедник «Оренбургский»: история создания и природное разнообразие. Екатеринбург: Институт степи УрО РАН, Оренбургское отделение Русского географического общества. ООО «УИПЦ», 2014. 139 с.

6. Красная книга почв Оренбургской области / А.И. Климентьев, А.А. Чибилёв, Е.В. Блохин, И.В. Грошев. Екатеринбург: УрО РАН, 2001. 296 с.

7. Добровольский Г.В. Почвы СССР. М.: Мысль, $1979.537 \mathrm{c}$.
8. Качинский Н.А. Физика почвы. Водно-физические свойства и режимы почв. М.: Высшая школа, $1970.358 \mathrm{c}$.

9. Инкин Л.А. Плотность почвы и физические процессы в ней. Ставрополь: Кн. изд-во, 1973. 64 с.

10. Тюрин А.Н. Чернозёмы Государственного природного заповедника «Оренбургский» // Объекты природного наследия и экотуризм: мат-лы междунар. науч.-практ. конф., Улан-Удэ - п. Гремячинск, 2527 августа 2014 г. / под общ. ред. проф. М.В. Слипенчука. М.: МГУ, 2014. С. 79-83.

11. Блохин Е.В. Экология почв Оренбургской области: почвенные ресурсы, мониторинг, агроэкологическое районирование. Екатеринбург: УрО РАН, 1997. 227 c.

12. Официальный сайт Объединённой дирекции государственных природных заповедников «Оренбургский» и «Шайтан-Тау» [Электронный ресурс] // https://orenzap.ru.

13. Бакирова Р.Т. Образован новый участок Оренбургского Заповедника // Степной бюллетень. 2015. № 45. C. 11-15.

14. Кэмпбэлл Ш. Реальна ли реинтродукция? // Биология охраны природы: Пер. с англ. / под ред. М. Сулея, Б. Уилкокса; пер. С.А. Остроумова; под ред. и с предисл. А.В. Яблокова. М.: Мир, 1983. С. 297-303.

15. Программа по восстановлению лошади Пржевальского в Оренбургской области / разраб.: В.В. Рожнов, Н.Н. Спасская, А.А. Чибилёв, С.В. Левыкин, В.Н. Орлов, Н.В. Паклина, М.К. Позднякова, Б.И. Петрищев. М.: Товарищество научных изданий КМК, $2010.32 \mathrm{c}$.

16. Левыкин С.В., Буров С.Н., Спасская Н.Н., Оренбургская Тарпания. Инновационный проект по сохранению и реабилитации степей. Оренбург: НПП «ИНЭЛ», 2005. $20 \mathrm{c.}$

17. Орлов В.Н., Паклина Н.В., Петрищев Б.И., Позднякова М.К., Спасская Н.Н. Предпосылки создания естественной популяции лошади Пржевальского (Equus przewalskii Poljakov, 1881) в степной зоне России // Вопросы степеведения. 2004. № 2. С. $25-30$.

18. Грудинин Д.А., Казачков Г.В. Предпосылки использования ревайлдинга для сохранения ландшафтов степной зоны на примере Оренбургской области // Трёшниковские чтения - 2018: Современная географическая картина мира и технологии географического образования: мат-лы всерос. науч.-практ. конф. / под ред. И.Н. Тимошиной, Е.А. Артемьевой, В.Н. Федорова и др. Ульяновск: ФГБОУ ВО «УлГПУ им. И.Н. Ульянова», 2018. С. 159-161.

19. Проект по реинтродукции лошади Пржевальского в Оренбургской области. [Электронный реcypc] // http://earaza.ru.

20. Дьяченко Е.С., Братуха И.В., Путилов А.А. Научные исследования: векторы развития: мат-лы III междунар. науч.-практ. конф. (Чебоксары, 30 нояб. 2018 г.) / редкол.: О.Н. Широков [и др.]. Чебоксары: ЦНС «Интерактив плюс», 2018. С. 9-11.

21. Тюрин А.Н. Реинтродукция лошади Пржевальского в Оренбургской области // Трёшниковские чтения - 2018: Современная географическая картина мира и технологии географического образования: мат-лы науч. конф. / под ред. И.Н. Тимошиной, Е.А. Артемьевой, В.Н. Федорова и др. Ульяновск: ФГБОУ ВО «УлГПУ им. И.Н. Ульянова», 2018. C. 209-211. 


\section{PRZEWALSKI'S HORSE REINTRODUCTION IN THE STATE NATURAL RESERVE «ORENBURGSKY»: THE FIRST RESULTS}

(C) 2019

Tyurin Alexandr Nikolayevich, candidate of geographical sciences, associate professor of Geography and Methods of Geography Teaching Department Orenburg State Pedagogical University (Orenburg, Russian Federation)

Abstract. This paper presents a chronology of the main events taking place within the framework of the program to resettle Przhewalsky's horses to the territory inhabited by their close relatives, the tarpans, to create a new and sustainable population of these animals. The Przewalski's horse population under natural conditions of the State Natural Reserve «Orenburgsky» will allow having a reserve of healthy, well-developed animals as a guarantee of keeping the species clean for a very long period of time. By the end of the $19^{\text {th }}$ century, not a single Przewalski's wild horse remained in its natural habitat. The paper discusses a gradual reintroduction of Przewalski's horse and presents the first results, taken from open sources, on the restoration of the wild horse population in the Orenburg Region. The first results allow you to look to the future with confidence. 5 healthy foals have already been born in the reserve; PA scientists are optimistic about the spring of 2019 and hope that the stock of wild horses will continue to grow. The Przewalski's horse reintroduction program enjoys a personal support of the Orenburg Region Governor and is among the key projects for the protection of wild animals, personally supervised by the President of the Russian Federation.

Keywords: Przewalski's horse; wild horse; harem group of animals; endangered species; Orenburg Region; State Natural Reserve «Orenburgsky»; cluster reserve; Pre-Ural steppe; «Orenburg Tarpania»; historical area; reserved mode; population; acclimatization.

УДК 576.895.42

DOI 10.24411/2309-4370-2019-11121

Статья поступила в редакцию 25.12.2018

\section{ОЦЕНКА УСТОЙЧИВОСТИ СООБЩЕСТВ ЭКТОПАРАЗИТОВ РУКОКРЫЛЫХ С ПОМОЩЬЮ МЕТОДА ГЛАВНЫХ КОМПОНЕНТ (РСА)}

(C) 2019

Фадеева Галина Анатольевна, кандидат биологических наук, доцент кафедры ботаники и зоологии

Борякова Елена Евгеньевна, кандидат биологических наук, доцент кафедры ботаники и зоологии Национальный исследовательский Нижегородский государственный университет им. Н.И. Лобачевского (2. Нижний Новгород, Российская Федерация)

Аннотация. В пещерах естественного происхождения (юг Нижегородской области) проведены исследования сообществ эктопаразитов шести видов рукокрылых. С помощью метода главных компонент (РСА) оценена устойчивость сообществ эктопаразитов рукокрылых. Поскольку пещеру и ее обитателей можно рассматривать как микробиотоп, то очевидно, что в нем складываются специфические отношения между обитателями. Особые условия обитания опосредованно влияют на складывающиеся там паразитарные системы, которые характеризуются определенной устойчивостью. Предварительно при помощи критерия МаннаУитни оценивалось различие между выборками животных из разных местообитаний. Методы непараметрической статистики не обнаружили достоверных различий по хозяевам, годам и биотопам, и колонию рукокрылых и их эктопаразитов можно оценивать как единую сложно организованную систему, длительно существующую в пространстве и времени. Из всех возможных факторов среды на системы оказывают существенное влияние четыре, вклад первых двух равен 65\% дисперсии (видовая специфичность паразита к хозяину и фактор присутствия видов-доминантов). В сообществе эктопаразитов рукокрылых установились такие взаимосвязи, которые обусловливают успешное существование всех видов без выраженной конкуренции. Каждый вид имеет свою позицию в факторном пространстве. В сообществах эктопаразитов рукокрылых встречаются виды, которые связаны высокой корреляционной зависимостью только с одним фактором (Spinturnix acuminatus, Sp. plecotinus, Leptotrombidium russicum), но обнаруживаются и виды, которые демонстрируют как умеренно-положительные, так и умеренно-отрицательные корреляционные зависимости не с одним фактором, а с несколькими. Например, Spinturnix myoti, Sp. kolenatii, Macronyssus heteromorphus и др. Неодинаковое воздействие среды на паразитарные системы, формирующиеся в пещерах естественного происхождения, обеспечивает устойчивость сообществ эктопаразитов рукокрылых в целом.

Ключевые слова: паразитарная система; рукокрылые; эктопаразиты рукокрылых; карстовые пещеры; Нижегородская область; Среднее Поволжье; гамазовые клещи; спинтурнициды; никтерибеиды; метод главных компонент (РСА); устойчивость сообществ; сообщества паразитов; специфичность паразитов к хозяевам.

\section{Введение}

Паразитарные системы - это саморегулирующиеся экологические системы, в которых отношения между партнерами находятся в состоянии подвижного равновесия. Паразиты могут регулировать плотность своих популяций с помощью механизмов с обратной связью, что приводит к формированию Самарский научный вестник. 2019. Т. 8, № 1 (26) устойчивых, хотя и динамичных паразитарных систем. Устойчивость в пределах системы «паразитхозяин» может значительно варьировать $[1 ; 2$, с. 350 ; 3-5]. Одним из механизмов регуляции численности популяций паразитов является агрегированный характер распределения, подчиняющийся модели отрицательного биномиального распределения [5; 6; 7, 